\title{
Sita: The Justly Emancipated Woman in Chitra Banerji Divakaruni's The Forest of Enchantments
}

\author{
Geetanjali Rathore(Ph.D) \\ Lecturer English \\ Himachal Adarsh Sanskrit College
}

\begin{abstract}
:
Sita has always been described as a docile and meek woman sine ages. The Indian English writers of the twenty first century has totally changed the age old narrative and brought out in the society the valiant and courageous Sita. Some writers focus her as awarrior, others as a very courageous woman who has no time to indulge in self pity. Chitra Banerjee Divakaruni also focuses on the courageous and most witty side of her Sita. she shows her wit in the management of the household. How sita deftly keeps the male ego under control and makes her emancipated is the focus of the present paper. Male ego and suppression are alos the focus of this paper.
\end{abstract}

Key words: Emancipation, male ego, gender ideology, norms.

In the recent times there has been a plethora of Indian writers writing on the life of Sita and Ramayana. All of them carve her as a strong willed courageous woman and not as a weeping weakling. It is like rewriting the history and presenting the future generations with a more favorable and acceptable example. The Sita depicted in Ramayana does not present a parallel example to the emancipated woman of today. Indian English Writers have granted totally new dimension to Sita's life and examined it and created an altogether different paradigm. Sita in the novel does stand up against Patriarchy but in her own silent and docile manner. It is only in the end she unleashes her power and energy and does the unbelievable. Present paper focuses on the kind of emancipation Sita depicts while staying in the palace or forest. She sets an example to the modern woman about how to deftly to keep male ego under control without their obvious knowledge. She reflects the norms of gender ideology that might lie beneath some normal everyday conversations. Divakruni's sita sets a totally different example of emancipation for the modern woman.

Ramayana has been an epic of prime importance for all the Hindus since the Vedic ages. The Protagonists Rama and Sita are held up as example to the young men and women of society. All the men and women are expected to emulate the characteristics of Sita and Rama. The recent flux in the term called gender has brought the society to question the roles of both this exemplary couple. Ram's judgment for sending Sita into exile is questioned from the gender perspective, where as Sita is carved as a strong and emancipated woman. She has been brought down from a pedestal of a Goddess and her sorrows and joys and examined form a human perspective. A plethora of novels by the Indian English writers about Ramayana with special focus on Sita are instrumental in bringing about the powerful and emancipated persona of Sita. Amish Tripathi in his Sita : The warrior of Mithila present sita not as a weak woman but as an agile warrior. Dev Dutt Patnayak in his Sita recasts Sita as a strong willed woman who is daring since her childhood. She is someone who bears a stay of fourteen years in the forest despite being a queen. Her strength of love for Ram hold her true to him despite Ravan's alluring her with one thing or the other. Bringing up her children as a single parent and later going back to her source are some of the most interesting parts of the novel. Sitayana by Amit Majumdaar also depicts her as a strong woman where she stays away from all her comforts in Lanka for the sake of her husband Ram. He also glorifies her single parenting even during Vedic ages. Samhita Arni and Moyna Chitrakaar's Graphic novel Sita's Ramayana includes a woman's perspective form the view point of wars and kingdom expansion. She focuses on how woman are treated as pawn in kingdom 
extension or waging a war. Chitra Banerjee Divakaruni's The Forest of Enchantments focuses on how gender ideology works to suppress or simply ignore women as playthings. On the flipside Divakaruni shows the strong emancipated character of Sita. Sita is a strong woman, who takes her decision smartly and sometimes even manipulates Ram, her beloved. In this novel Divakaruni also marvels on the different natures of love and tries to depict, how everything and every situation on injustice is done in the name of love.

The turbulence and agitation in sita's mind is seen when she speaks loudly to Rishi Valmiki. In the beginning she insists on writing her story by herself and on receiving his consent and blessings pens down the Sitayana. Immediately after marriage Sita feels the sting when Dashratha forbids her to take her maid along to Ayodhya. He does not honor even the request of Queen Sunaina there by depicting to Sita his power and suppression. Ram's wait for his father and grant his consent after fulfilling his bride price worries Sita. She questions in her mind that ram should have taken consent before fulfilling the bride price. Next moment She felt a surge of respect for Ram when he declared that he would wait for his father to be present at the wedding but this makes her reflect on her own status in his life. Her words, "And suddenly I was angry. Filial duty was important to Ram. Good. But what of his duty towards me."( Divakaruni 35) When she thinks deeply she realizes that Ram should not have broken the Dhanush if he wanted to take permission from his father for marrying her. Sita was expected to stay quite during her swayamvar but she spoke and suggested her cousins to be the brides of his younger brother. Sita feels embarrassed later for speaking to Ram before marriage in front of everybody but something tells her from inside that," It's important to speak your mind to the man you are going to marry. What kind of relationship would you have if you didn't speak up your mind?"'( Divakaruni36) When Sita finds a solution to Ram's problems she sees a flicker in his eyes and interprets it as a respect for herself but later tells herself that it might be the 'surprise that a mere girl could untangle such a knotty situation.'(Divakaruni 37) Sita was an intelligent woman and aware of her rights and how to protect them. When Ram discusses with her, his kingly duties Sita only wonders," Where did a wife fit in among all his responsibilities to his lineage, his family and his Kingdom?"(Divakaruni 39) To question for one's own status and look for rights and duties are the first step towards achieving emancipation and Sita's constant questioning present her as a person who could not be suppressed easily.

Sita marvels at the surprise of the courtiers in the swayamvar hall when Ram declares that he would never take another wife after Sita. Sita thinks that it is not a great sacrifice by Ram but actually the exact way to be. She also thinks about the position of her mother's -in-law with the exception of keikai. She believes that kings are wrong and queens have to pay the price. This stands true in the context of Dashrath and his queens, Ram and his queen, Ravan and his queen, Vibheshana and his wife and Lakshamana and his wife. Surprisingly it is the decision of men that drag women along with them to suffer.

Male ego and authority is not something to be preserved but Sita did that artfully so that it did not come in the way of her freedom. She confesses that she had 'learned the right way to approach Dashrath in a way so that he did not feel his authority was threatened. As a result he had grown quite fond of me like a daughter'.( Divakaruni 86) Sita did recognize the male ego but she used it to her own purpose in her own way. Sita very intelligently talks to Ram about taking her to forest with him. Ram was expecting 'histrionics' (Divakaruni 111) from her but she did not indulge in them but calmly spoke to Ram in the terms of Duty and right. She says,"Duty. Right these are the terms which Ram understood best, so I used them. But underneath them I was saying, I love you, don't abandon me".(Divakaruni 112) She did go to the forest with Ram but without losing her self-respect in crying. She persuaded Ram without even pleading him for once. Their lies the emancipation and wittiness of her persona. When Lakshaman warned her against the forest creature and advised her they might be shape shifters she says," I nodded, mostly to keep peace. I'd learned by now that Lakshaman did not like being contradicted".(Divakaruni146) She recognized everybody's weaknesses and used them for her benefits however required. It was in surpnakha's case Sita could not do anything and felt guilty about it. She felt ashamed at the behavior of her husband and Brother -in-law. She asked a genuine question to herself that," do we women trust too much when we love? Do we expect our men to solve every problem that comes up? (Divakaruni 147)Sita's statement questions the fragile nature of women wherein she surrenders everything to him along with her commonsense sometimes which should not be the case. Sita understood the superiority complex of the males so she did not traverse much further with Ram and 
Lakshman in any discussion. She said," their belief in the superiority of their own ways was too deeply ingrained in them. I did not argue any further".(Divakaruni 151)

When Ram demands her to undergo agni pariksha for the sake of Dharma she stoically questions him. She reasons that it is not dharma to leave his wife as that would spur other men of his kingdom to abandon their wives for their slightest mistakes. She questions him," is that Dharma? Is that what you want"? (Divakaruni 242) Sita's intellectual question does not have any effect of Ram and he propels Sita to take the Agni Pariksha.

When Lav and Kush return to Ayodhya along with Sita and Ram once more asks Sita to take the agni pariksha and Sita rejects it out rightly. She declares to Ram that she would not take the agni pariksha and surrender herself to agnidev. While leaving she advises her sons that there can always be a balance between Dharma, Duty and Love. Her advice to her sons is like a reminder to the reader of what her beloved Ram could not do for her. She keeps no place in her mid and heart for self pity and anger. She blesses the kingdom and leaves a message for her unborn daughters," I bless my daughters who are yet unborn. I pray that, if life tests them - as sooner or later life is bound to do- they'll be able to stand steadfast and think carefully, using their hearts as well as their heads, understanding when they need to compromise, and knowing when they must not. Because this is one of those times when a woman must stand up and say no more". ( Divakaruni 357)

The Forest of Enchantments presents the emanation of a powerful persona of Sita. Her message of 'no more' to the future generations is the panacea to undo the ideological gender suppression. It is clear that Sita has used her own ideology in the novel to overcome the suppression of her life. After keen observation it can be said Divakaruni's The Forests of Enchantments is like a help book to the modern woman for emancipation. It is clear that," Apart from the stylistic flair, one of her major strengths is her unravelling of multiple dimensions of characters. Sita comes across as a fierce conservationist, dutiful but bold daughter, protective sister, loving yet wilful wife, perfect helpmate, sensual lover, courageous fighter, skilled healer, learned counselor, strong mother, kind yet firm daughter-in-law, nurturer and adventurer. She revels in her own being, is mindful of pleasure and grief, of empathy and understanding, and is brimming with dignity for herself and for everyone else. She is the original feminist".( Bhattrai)

\section{Works cited}

1. Bhattrai,Richa. Sita, Through Her Own Eyes. Book Review: The Forest of Enchantments by Chitra Banerjee Divakaruni. The Wire, 20 Jan 2019

2. Divakaruni,Chitra Bannerjee. The Forest of Enchantments.Harpercollin,2019.

3. Krishna Chatur Sow Mondal, Dr. S. Lavanya. (2020). Voyage into Chitra Banerjee Divakaruni's The Forest of Enchantments. International Journal of Advanced Science and Technology, 29(9s), 7031 7035. Retrieved from http://sersc.org/journals/index.php/IJAST/article/view/21208 